\title{
Using GIS for the Comparison of Intrinsic Parametric Methods Assessment of Groundwater Vulnerability to Pollution in Scenarios of Semi Arid Climate. The Case of Foussana Groundwater in the Central of Tunisia
}

\author{
Sami Khemiri ${ }^{1}$, Afef Khnissi ${ }^{2}$, Mohsen Ben Alaya ${ }^{1}$, Salwa Saidi ${ }^{3}$, Fouad Zargouni ${ }^{1}$ \\ ${ }^{1}$ Department of Geology, University of Sciences, Tunis, Tunisia \\ ${ }^{2}$ Water Research and Technology Center, Borj Cedria, Solimane, Tunisia \\ ${ }^{3}$ Water, Energy and Environment Laboratory (LR3E), ENIS, Sfax, Tunisia \\ Email: khemirisami_geo@yahoo.fr, afefkhnissi@gmail.com, benalaya.mohsen@gmail.com, \\ salwa_saidi@yahoo.fr, fouadzargouni@yahoo.fr
}

Received March 17, 2013; revised May 6, 2013; accepted June 9, 2013

Copyright (C) 2013 Sami Khemiri et al. This is an open access article distributed under the Creative Commons Attribution License, which permits unrestricted use, distribution, and reproduction in any medium, provided the original work is properly cited.

\begin{abstract}
Groundwater vulnerability maps have become a standard tool for protecting groundwater resources from pollution. They are especially valuable in the decision making process related to land use planning. In fact, mangers have mostly little experience and expertise at hand to decide which land uses and activities are to be allowed in certain areas without causing a negative impact on the quality of groundwater. Hence, numerical modeling of various hydrological parameters and assessment of vulnerability to potential pollution of water resources in Tunisia has been the subject of several studies since 1980. These water resources are becoming increasingly scarce, overexploited, poorly distributed and most especially polluted including Mioplio quaternary Foussana Aquifer located in the western of the Kasserine area in the central Tunisia, which is considered as an economic resource priority because it is used in irrigation and domestic consumption. The area of the aquifer is essentially occupied by agricultural areas characterized by an important use of chemical fertilizers which are in addition to the discharge of industrial zones, an ongoing risk to the groundwater quality; this prompts us to a hydrological study and vulnerability late attributed to improve management of water resources in the study area. In this context, the use of GIS and remote sensing seems to be an effective tool the aquifer vulnerability evaluation, by applying various methods: standard DRASTIC, GOD, SINTACS and SI. The application of these methods shows that the most vulnerable zone is the southern part of the Foussana aquifer. So these maps could serve as a scientific basis for sustainable land use planning and groundwater management in the study area.
\end{abstract}

Keywords: Vulnerability; DRASTIC; GOD; SINTACS; SI; GIS

\section{Introduction}

Generally, irrigation in arid regions is always changing due to many factors: low rainfall, high evapotranspiration, groundwater quality, structural and soil condition. Increasing populations and high living standards in most arid countries causes excessive water demands used in industries and urban needs. Water used in irrigation has also been s an important water demand. In arid regions, overexploitation of groundwater induced alarming declines in water levels [1].

Remediation of contaminated aquifers is expensive. To recognize the need to an efficient method to protect groundwater resources from contamination, scientists and managers develop aquifer vulnerability techniques for predicting which areas are the most vulnerable [2].

The assessment of groundwater vulnerability to pollution has been the subject to intensive research during the past years and a variety of methods have been developed. Many approaches have been developed to evaluate aquifer vulnerability. For this objective, the GIS and remote sensing tools are combined to various methods: standard DRASTIC, GOD, SINTACS and SI method. They are used to evaluate aquifer vulnerability to pollution. Finally, a comparative study of the vulnerability maps was performed in order to choose the best method. 


\section{Methods}

\subsection{Principe}

Numerous vulnerability modeling approaches is proposed. A comprehensive groundwater vulnerability model must include parameters to describe how much a site is risky to be contaminated and how the contaminant moves from the contamination site to the aquifer. In this study, the vulnerability rating used is the DRASTIC index, GOD index, SINTACS index and SI index (Aller, 1987) (Figure 1).

For each used models we have applied the following formulas:

Equation (1) DRASTIC is

$$
\begin{aligned}
I D= & D p \times D c+R p \times R c+A p \times A c \\
& +S p \times S c+T p \times T c+I p \times I c+C p \times C c
\end{aligned}
$$

$D$ : Depth; R: Recharge; A: Aquifer lithology; $S$ : Soil T: Topography; I: Unsaturated zone; $C$ : hydraulic Conductivity.

Equation (2) GOD is :

$$
I G O D=C i \times C p \times C a
$$

Ci: Aquifer type; $C p$ : depth \& Ca: saturated zone.

Equation (3) is SINTACS:

$$
\begin{aligned}
I S= & S p \times S c+I p \times I c+N p \times N c+T p \times T c \\
& +A p \times A c+C p \times C c+S p \times S c S
\end{aligned}
$$

$S$ : Depth; I: Recharge; $N$ : Vadose zone; $T$ : Soil type; $A$ : Hydrogeological characteristics aquifer; $C$ : Conductivity \& S: Slope.

Equation (4) is:

$$
\begin{aligned}
I S= & D p \times D c+R p \times R c+A p \times N c \\
& +T p \times T c+O S p \times O S c
\end{aligned}
$$

$D$ : Depth, R; Recharge; A: Lithology; $T$ : Topography \& OS: Soil Occupation.

The parameters mentioned above are defined and de- termined as follows.

\subsubsection{Depth (D)}

It represents the depth from the land surface to the first groundwater aquifer [3]. It determines the thickness of material through in which infiltrating water must move before reaching the aquifer-saturated zone. Consequently, the depth of the groundwater impacts on the interaction degree between the percolating contaminant and subsurface materials (air, minerals, water) and, therefore, on the degree and extent of physical and chemical attenuation, and degradation processes, the depth groundwater distribution (D) was established by subtracting the groundwater level, measured in forty wells in Foussana aquifer, from the topographic elevation in the corresponding cell location [4].

Before starting detailed data collection, some general information pertaining to the socio-economic, demographic and physical characteristics, settlement patterns, and water supply schemes of the communities under study were gathered. This information has been used as a base for planning the field data collection and determining the selection of the sample population [5].

\subsubsection{Net Recharges (R)}

One of the major impacts of the integrated watershed management program was on improving groundwater recharge and its availability [6]. To calculate the recharge parameter distribution, the Water Table Fluctuations method (WTF) was used. It estimates groundwater recharge as the product of specific yield and the annual rate of water table rise added to the total groundwater draft [7] ended by the equivalent permeability, which is found from well logs [8].

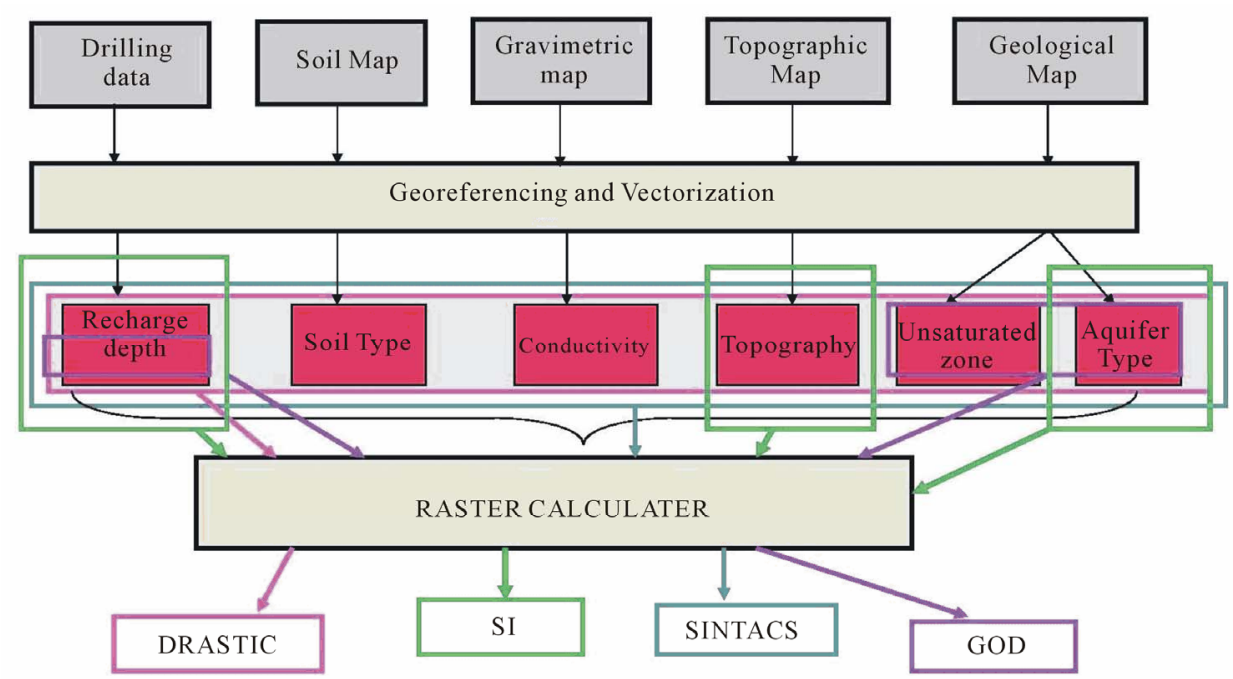

Figure 1. Flow chart of methodology for groundwater pollution vulnerability analysis. 


\subsubsection{Topography (T)}

It refers to the slope percent of the land surface which was determined directly from the topographic maps of Kasserine, Berino, Semmama and Bouchebka (scale 1:50,000).

\subsubsection{Soil Media (S)}

The soil parameter (S) was obtained by digitizing the existing soil maps, with 1:50 000 as a scale required from Regional Agency of Agriculture Laboratory "CRDA", which they cover the entire region.

\subsubsection{Hydraulic Conductivity (C)}

The hydraulic conductivity is defined as the ability of aquifer materials to transmit water, which in turn, controls the rate at which groundwater will flow under a given hydraulic gradient. The rate, at which the groundwater flows, also controls the rate at which it enters the aquifer [9]. The hydraulic conductivity was calculated based on the following equation:

$\mathrm{K}$ is the hydraulic conductivity of the aquifer $(\mathrm{m} / \mathrm{s})$, $\mathrm{b}$ is the thickness of the aquifer $(\mathrm{m})$ and $\mathrm{t}$ is the transmisivity $\left(\mathrm{m}^{2} / \mathrm{s}\right)$, measured from the field pumping test data.

\subsection{Study Area}

The study area is located in the foreland of the Alps, in the western part of central Tunisia [10]. It is limited in the east by Kasserine region, Algeria in the west, Sidi Bouzid region in the south and Siliana region in North. The sector is marked by a pool. Its collapse due to mainly extensional tectonic events in the boundary of this basin [11].This basin is surrounded by folded structures: Jebel Semmama, Jebel Biréno, Jebel Hamra in the West [12], and Jebel Chambi in the East [13] (Figure 2).

The main outcrop that marks the watershed of Foussana is the quaternary alluvium which is surrounded by Cretaceous reef of deposits covering folds Mountains bounding [14].

The Foussana watershed is a part of Wadi Zroud hydrological large set. The basin has a relatively streams. The most important is Wadi El Hatob .It crosses the basin along its entire length and thus constitutes the main drain of this basin.

\section{Results}

\subsection{Data Processing and Parameters Evaluation}

For each parameter a raster map is made from interpolation of the well data using the Arc View GIS software. Map of soils is scanned and then processed from the Soil Map. The slope map is obtained from the digital elevation model. Each parameter is classified on certain vulnerability classes with values from the DEM [15].
The attribution to each parameter the corresponding weight and rating according the formula of each method in order to obtain the vulnerability indexes. All parameters in different models are mapped [16]. Using the Kriging interpolation technique; we have been allowed to map the distribution of each parameter.

The alluvial Foussana aquifer is important water resource because it is used for irrigation. The aquifer vulnerability to pollution by generic pollutants has been studied by applying the following methods:

\subsubsection{DRASTIC Method}

This is one of the most used methods in the world.

It assigns a note between 1 and 10 and a weight between 1 and 5 for each used parameter (Table 1).

\subsubsection{GOD Method}

The GOD method is an empirical method for the assessment of aquifer pollution vulnerability.

Developed in Great Britain; this method uses three parameters: 1) Groundwater occurrence, 2) Overlying lithology (solely related to the unconfined aquifers) and 3) Depth to groundwater. Values from 0 to 1 can be assigned to the parameters (Table 2).

\subsubsection{SINTACS Method}

The SINTACS method was established for hydrogeological, climatic and impacts settings, typical of the Mediterranean countries.

The acronym SINTACS stands for the seven parameters included in the method: depth to water, recharge, vadose zone, soil cover, aquifer, hydraulic conductivity and slope. In the same way that the DRASTIC method, SINTACS assigns notes and weights for each of these parameters in the following way (Table 3).

\subsubsection{SI Method}

SI (Susceptibility Index) method (Ribeiro, 2000) is a vulnerability method for evaluating the specific vertical vulnerability to pollution originated by agricultural activities mainly by nitrates.

Specific vulnerability is the term used to define the vulnerability of groundwater to a particular contaminant or group of contaminants.

SI assigns notes and weight for each of these parameters in the following way (Table 4).

\subsection{Spatial Mapping of Calculated Parameters}

After classifications and notifications for each parameter, the spatial mapping in Raster format by interpolation of these parameters is a necessary step in this work [17]. In this case we obtain the result shown in Figures 3-6.

All the realized maps are projected in "WGS 1984 UTM Zone 32N, datum Carthage." 


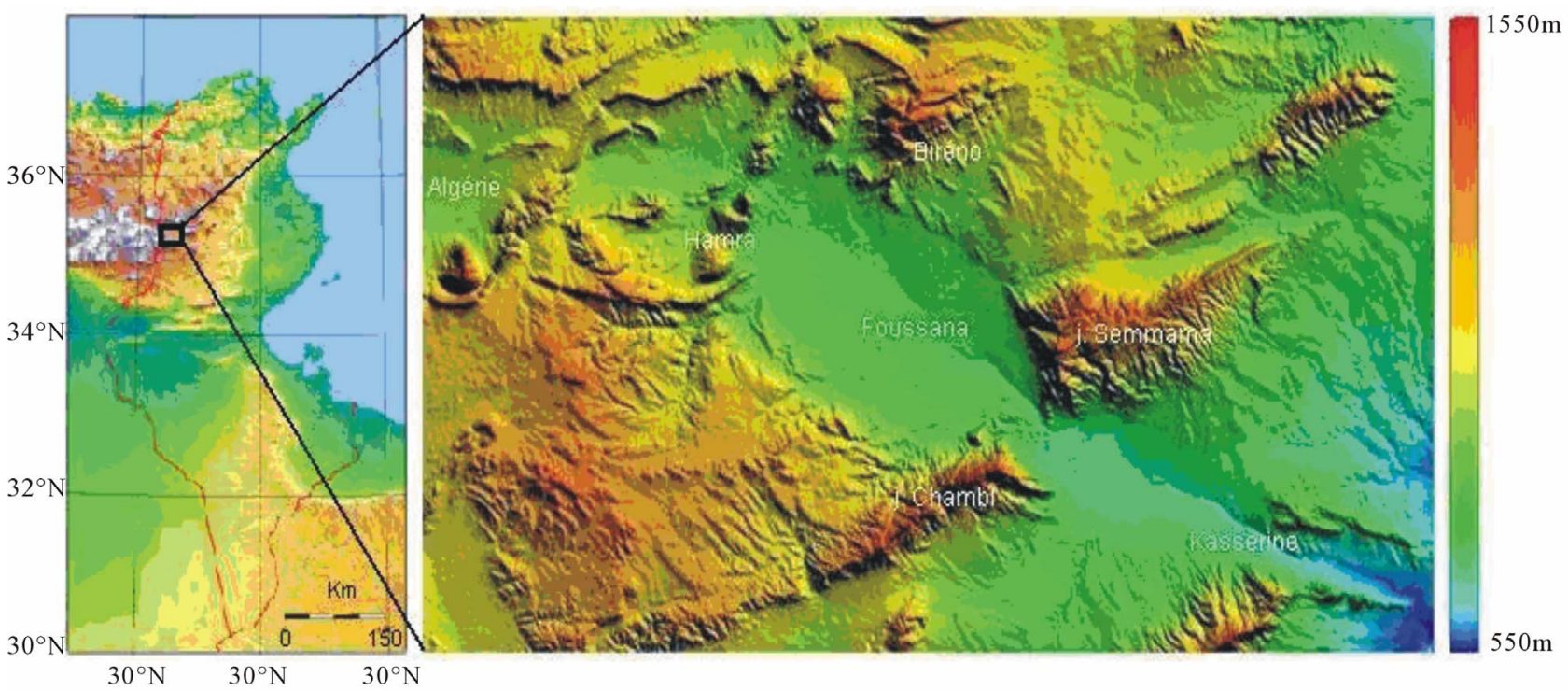

Figure 2. Study area.

Table 1. Attribution of notes for DRASTIC. model parameters.

\begin{tabular}{|c|c|c|c|c|c|c|c|}
\hline Class D (m) & Note & Class A & Note & Class S & Note & Class C (en m/s) & Note \\
\hline $0-1.5$ & 10 & Massive shale & 2 & Thin or absent & 10 & $1.5 \times 10^{-7}-5 \times 10^{-5}$ & 1 \\
\hline $1.5-4.5$ & 9 & Métamorphic & & Gravels & 10 & $5 \times 10^{-5}-15 \times 10^{-5}$ & 2 \\
\hline $4.5-9$ & 7 & Altered - Sandstone & 0 & Sands & 9 & $15 \times 10^{-5}-33 \times 10^{-5}$ & 4 \\
\hline $9.0-15.0$ & 5 & massive limestone & 8 & Sandy Silts & 6 & $33 \times 10^{-5}-5 \times 10^{-4}$ & 6 \\
\hline $15-23$ & 3 & massif Sandsone & 6 & Silty loam & 3 & $5 \times 10^{-4}-9.5 \times 10^{-4}$ & 8 \\
\hline $23-30$ & 2 & Sand and gravel & 8 & Shales & 1 & $>9.5 \times 10^{-4}$ & 10 \\
\hline$>30$ & 1 & Karstic Limestone & 10 & \multicolumn{2}{|c|}{ Class I } & \multicolumn{2}{|l|}{ Note } \\
\hline Class R (mm) & Note & Class $\mathbf{T}\left(^{\circ}\right)$ & Note & \multicolumn{2}{|c|}{ Silt and Shales } & \multicolumn{2}{|l|}{3} \\
\hline $0-50$ & 1 & 0 à 2 & 10 & \multicolumn{2}{|c|}{ Shale } & \multicolumn{2}{|l|}{3} \\
\hline $50-100$ & 3 & 2 à 6 & 9 & \multicolumn{2}{|c|}{ Limestones } & \multicolumn{2}{|l|}{3} \\
\hline $100-175$ & 6 & 6 à 12 & 5 & \multicolumn{2}{|c|}{ Sandstones } & \multicolumn{2}{|l|}{6} \\
\hline $175-225$ & 8 & 12 à 18 & 3 & \multicolumn{2}{|c|}{ Sand and gravels with passage silt and Shale } & \multicolumn{2}{|l|}{6} \\
\hline$>225$ & 9 & $>18$ & 1 & \multicolumn{2}{|c|}{ Sand and gravels } & \multicolumn{2}{|l|}{8} \\
\hline
\end{tabular}

Table 2. Attribution of notes for GOD. model parameters.

\begin{tabular}{cccccc}
\hline Aquifer type Ci & Note & Depth Ca (m) & Note & Lithology Ca & Note \\
\hline None aquifer & 0 & $<2$ & 1 & Residual Soil & 0.4 \\
artesian & 0.1 & $2-5$ & 0.9 & Limon alluvial; Loess; Shale, fine Limestone & 0.5 \\
confined & 0.2 & $5-10$ & 0.8 & Aeolian Sand; Siltite; Tuf; igneous Rock & 0.6 \\
semi-confined & 0.3 & $10-20$ & 0.7 & Sand and gravel; Sandstone; Tufa & 0.7 \\
Free with cover & $0.4-0.6$ & $20-50$ & 0.6 & Gravel & 0.8 \\
Free with cover & $0.7-1$ & $50-100$ & 0.5 & Limestone & 0.9 \\
& & $>100$ & 0.4 & Fractured or karstic Limestone & 1 \\
\hline
\end{tabular}


Table 3. Attribution of notes for SINTACS. model parameters.

\begin{tabular}{|c|c|c|c|c|c|}
\hline Depth (m) & Note & soil texture & Note & aquifer lithology & Note \\
\hline $0-1.3$ & 10 & Gravel & 0.4 à 0.55 & coarse alluvium & $8-9$ \\
\hline $1.3-2.6$ & 9 & Sand & 0.3 à 0.55 & limestone karst & $9-10$ \\
\hline $2.6-3.9$ & 8 & sandy soil & 0.3 à 0.5 & fractured dolomite & $4-7$ \\
\hline $3.9-5.6$ & 7 & sandy Shales & 0.15 à 0.4 & alluvium medium to fine & $6-8$ \\
\hline $5.6-8.2$ & 6 & limonate-sandy Shales & 0.1 à 0.35 & complex sandy & $7-9$ \\
\hline $8.2-10.8$ & 5 & Limon & 0.05 à 0.2 & Sandstones, conglomerates & $4-9$ \\
\hline $10.8-16.5$ & 4 & Silty loam & 0.03125 à 0.15 & turbidite sequence (flysch) & $5-8$ \\
\hline $16.5-24.3$ & 3 & Shaled loam & 0 à 0.03125 & marl, clay & $1-3$ \\
\hline $24.3-41.7$ & 2 & silty Shales & 0 à 0.03125 & coarse moraine & $6-8$ \\
\hline $41.7-100$ & 1 & Shales & 0 à 0.02 & Moraine medium to fine & $4-6$ \\
\hline alluvial coarse deposit & $8-9$ & absent soil or far from thick & $9.8-10$ & $2325.48-8640$ & 10 \\
\hline karstic limestone & $9-10$ & pure gravel & $9.7-10$ & $86.4-2325.48$ & 9 \\
\hline fractured limstone (fissured) & $9-6$ & pure sand & $8.9-9.5$ & $27.32-86.4$ & 8 \\
\hline fractured dolomite (fissured) & $4-7$ & sandy soil & $8-8.5$ & $8.64-27.32$ & 7 \\
\hline Average at fine alluvial deposits & $6-8$ & sandy shale & $6.2-7$ & $2.732-8.64$ & 6 \\
\hline Sandy complex & $7-9$ & sandy loam & $5.5-6$ & $0.864-2.732$ & 5 \\
\hline Sandstones. conglomerates & $4-9$ & shale-sandy silts & $4.5-5.2$ & $0.197-0.864$ & 4 \\
\hline plutonics rocks fissured & $2-4$ & loam - silts & $3.5-4.2$ & $0.061-0.197$ & 3 \\
\hline turbiditics sequences (flysch) & $5-8$ & silty loam & $3-4$ & $0.01-0.061$ & 2 \\
\hline volcanics rocks fissured & $8-10$ & shaled loam & $6-8$ & $8.6410^{-6}-0.01$ & 1 \\
\hline
\end{tabular}

Table 4. Attribution of notes for SI. model parameters.

\begin{tabular}{cccc}
\hline depth (m) & Note & Aquifer lithology & Note \\
\hline $0-1.5$ & 100 & massive shale & 20 \\
$1.5-4.5$ & 90 & igneous Rocks/métamorphic/alterated & $30 / 40$ \\
$4.5-9$ & 70 & Till & 50 \\
$9-15$ & 50 & Beds of sandstone, limestone and shale & 60 \\
$15-23$ & 30 & massive limestone & 60 \\
$23-31$ & 20 & Sand and gravel & Note \\
$>31$ & 10 & karstic limestone & 100 \\
Recharge (mm/an) & Note & Occupation of the soils & 90 \\
$0-50$ & 10 & Industrial discharge, discharge of refuse, mines & 80 \\
$50-100$ & 30 & Irrigated perimeters, rivers & 75 \\
$100-180$ & 60 & Carreer, chantier naval & 70 \\
$180-250$ & 80 & Artificial coverted zones, green zones & 50 \\
& 90 & Permanent crops (vines, orchards, olive-trees, etc/urbain zones discontinuous & 0 \\
& & Pastures and agro-forest zones. & \\
\end{tabular}

Under ArcGis; maps are classified by "symbology" and then are cut with the tool "Extract by Mask" then they will be recorded in Raster "Tiff" format.

The maps are then superposed through "ArcScene," and the final product of vulnerability has been deducted by the "Raster calculator" tool, using the formulas already defined previously and multiplying classified parameters by their equivalent weight. 


\subsection{Overlays Analysis}

Groundwater Contamination Risk Mapping is carried out by overlay of layers representing the different parameters in the parmetrics models.

Theoretically an overlay is necessary for each parameter; however some of parameters are frequently closely associated. In some areas the vadose zone and aquifer media are the same. In other areas, soil and topography are intimately related [18].

The data used to generate the Vulnerability index map is produced at a variety of scales. Values for hydraulic conductivity are frequently extrapolated from only a few points of reference or simply estimated from aquifer media. When creating the map it is therefore important to attempt to "justify" the scales by either making generalizations or finding the most detailed information available.

Finally, through a function specific to the GIS software-the overlay function, the various maps for each parametric model (DRASTIC, GOD, SINTACS and SI) are combined through the Map Calculator function from the Spatial Analyst extension resulting in the Vulnerability Map of groundwater (Figure 7).

After mapping all the parameters, the vulnerability maps were obtained by overlaying the individual maps and calculating the indices on a grid map (cells of $300 \mathrm{~m}$ $\times 300 \mathrm{~m}$ ). For each grid cell, the Vulnerability Index was calculated as the weighted sum of the parameters according to equation.

Finally, we have to evaluate the hydrologic settings which are present on the map. The areas on the final map are labeled with the appropriate hydrogeologic setting. The vulnerability index for each model is calculated and the final vulnerability map was subdivided into classes related to vulnerability degrees of according to the classification of Engel et al. (1996) [19].

\subsection{Discussion and Vulnerability Models Comparisons}

The comparison between DRASTIC, GOD, SINTACS and SI methods shows that the closest results are those from the method SINTACS and SI, modified versions of the DRASTIC method adapted to the Mediterranean climate, climate prevailing in the study area [20]. The DRASTIC vulnerability map, according to standard classical provides, in turn, more detailed results widely different from other methods (Figure 8).

Obtained vulnerabilities results indicate the high mapping vulnerability area [21]. The central part of Foussana basin is the most exposed part to contamination. It is a plain which crossed by the river of Hatob. The right bank of the river is a large area. The largest irrigation area is located at the left of the bank. DRASTIC method shows
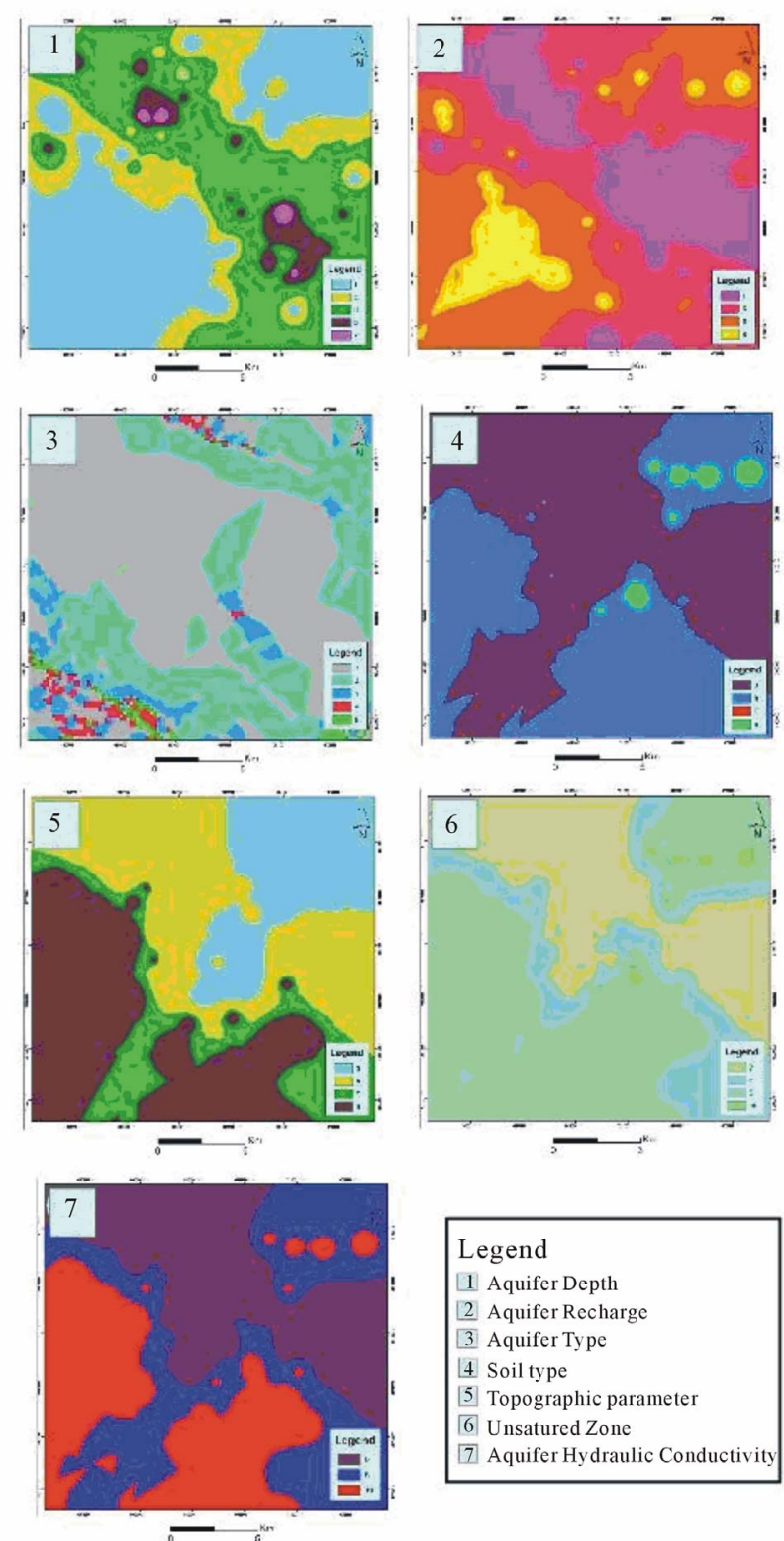

Figure 3. Mapping of DRASTIC model parameters.

the most vulnerable areas in Foussana basin to be polluted. The region is an area of high agricultural activity with an intense use of chemical fertilizers.

The DRASTIC map resulting from overlaying the seven thematic maps shows four classes, as indicated in (Figure 8).

The highest class of Vulnerability Index (VI: 161 - 200) (Table 5) covers $18 \%$ of the total surface in the central part of the study area. It is due to the high aquifer permeability coming from the vadose zone sediments nature.

The combination of quaternary alluvium and the Miocene sandstones, shallow groundwater $(<20 \mathrm{~m})$, high recharge $(>260 \mathrm{~m})$ and high hydraulic conductivity. This 

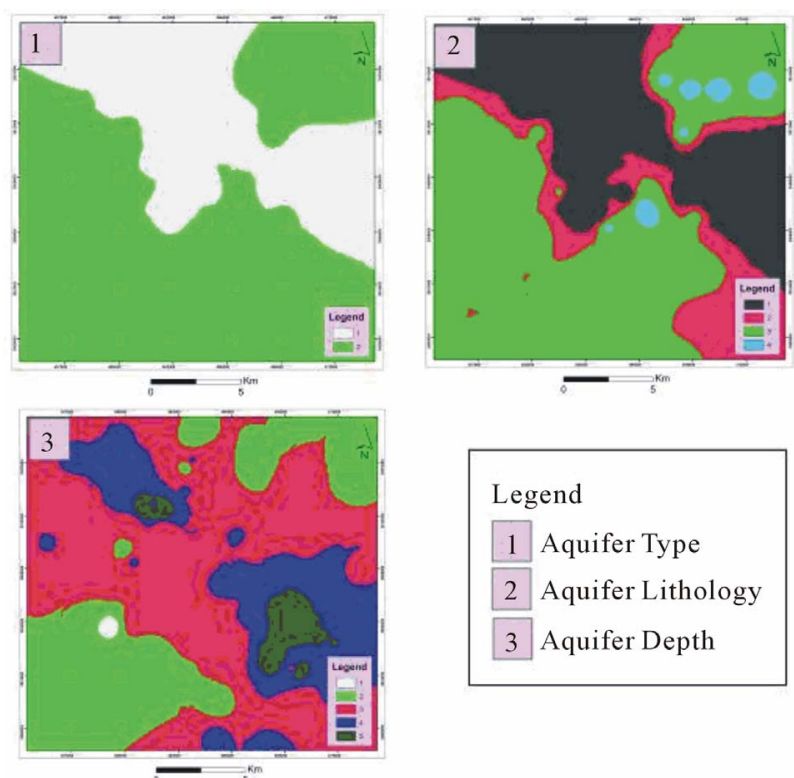

Figure 4. Mapping of GOD model parameters.
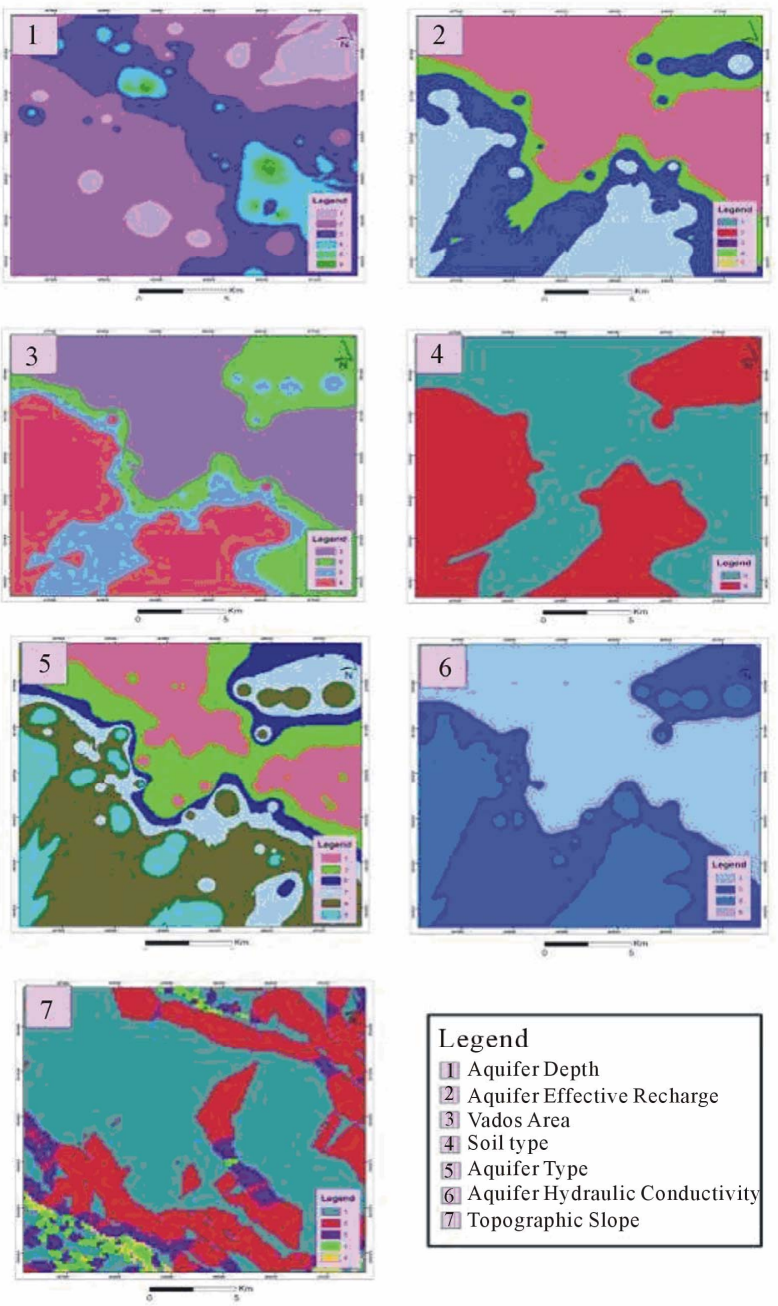

Legend

(1) Aquifer Depth

2] Aquifer Effective Recharge

3. Vados Area

4. Soil type

5] Aquifer Type

6] Aquifer Hydraulic Conductivity

7. Topographic Slope

Figure 5. Mapping of SINTACS model parameters.

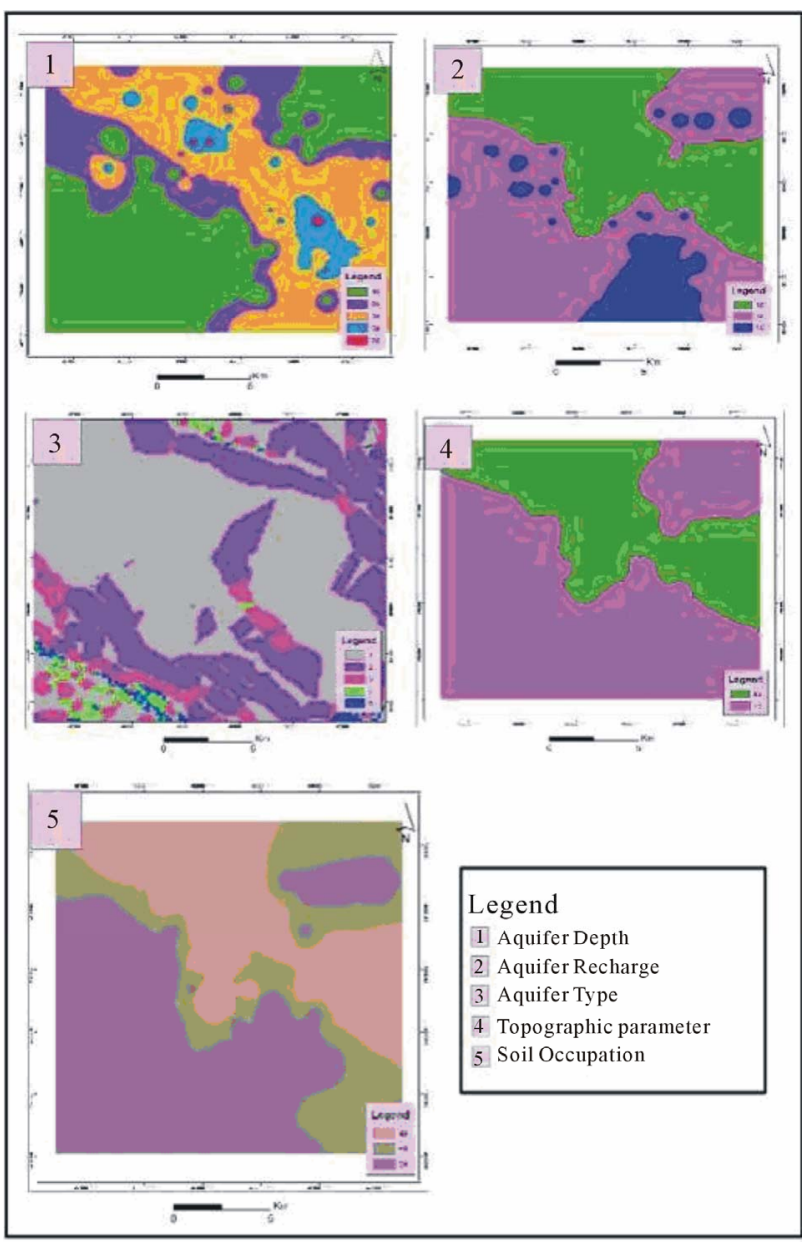

Figure 6. Mapping of SI model parameters.

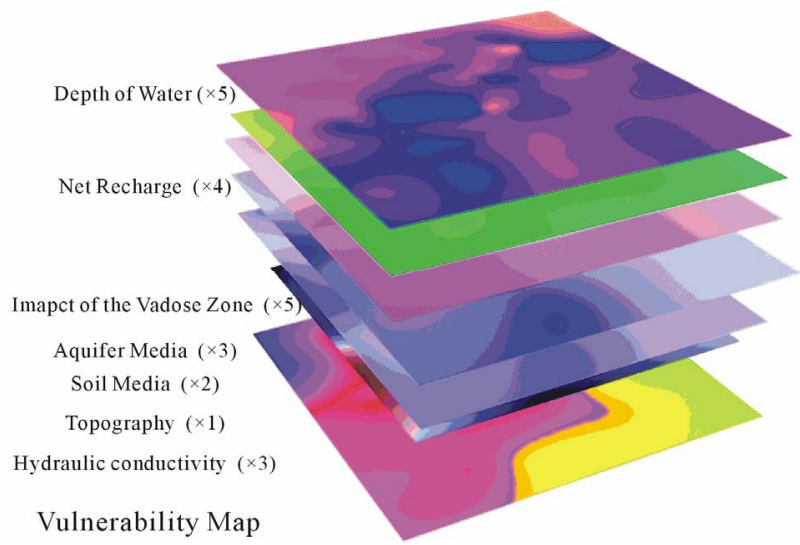

Figure 7. Overlaying of parameters (DRASTIC).

results in a low capacity to attenuate the contaminants. The very low vulnerability (VI: $1-60)$, which is represented by $10 \%$ of the total Foussana surface, is essentially due to the deep groundwater ( $>260 \mathrm{~m}$ depth), the low permeability and the vadose zone sediments ,added to that the low hydraulic conductivity [22]. As well as the low recharge rate, we assume that these are the same 


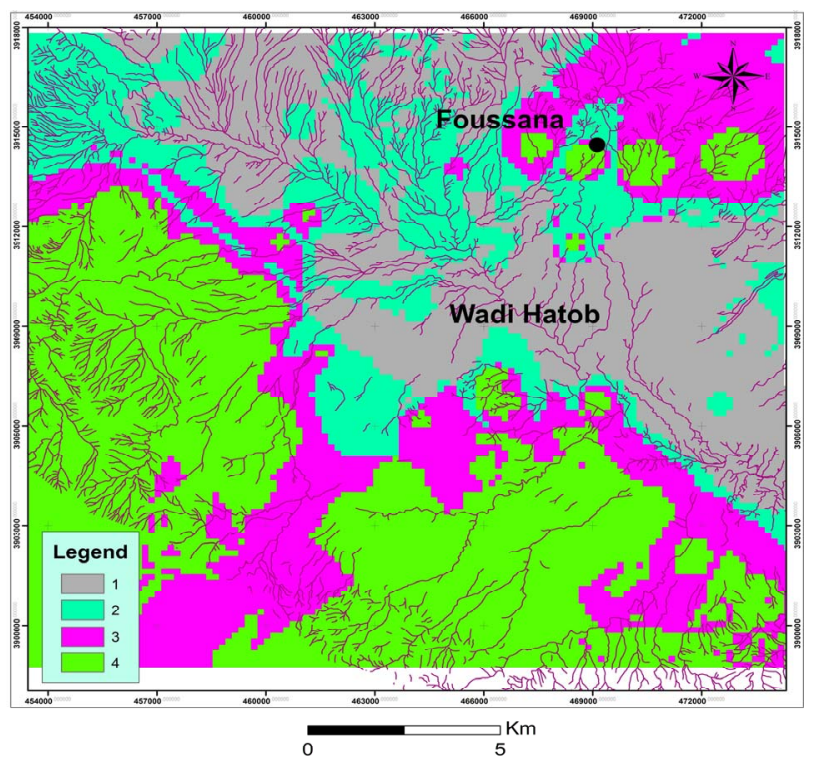

Figure 8. DRASTIC vulnerability map.

Table 5. Evaluation criteria of degree of vulnerability: DRASTIC model.

\begin{tabular}{cc}
\hline DRASTIC Vulnerability & Vulnerability index \\
\hline Very Low & $1-60$ \\
low & $61-120$ \\
Medium & $121-160$ \\
High & $161-200$ \\
Very high & $>200$ \\
\hline
\end{tabular}

conditions in the case of low vulnerability (VI: 61 - 120), with less degree of impact for these parameters. The moderate vulnerability (Medium value) (VI: 121 - 160) which is represent $10 \%$ of the study area. Vulnerability pattern is mainly dictated by the variation of the permeability [23] and the vadose zone. The recharge and the depth of groundwater are two parameters having a influence on vulnerability degrees to pollution (Figure 9).

The application of SI (susceptibility index method) indicates the very high vulnerable zones to be contaminated by pollutants (Figure 10).

The most vulnerable areas have an index between 85 and 100 (Table 6). Zones which have index value less than 45 are the less vulnerable.

The application of the SINTACS Model SI indicates the very high vulnerable zones to be contaminated by pollutants (Figure 11).

The most vulnerable areas have an index above than $>210$ (Table 7). Zones which have index value less than 45 are the less vulnerable.

The GOD Model application indicates the very high vulnerable zones to be contaminated by pollutants (Figure 12).

The most vulnerable areas have an index between 0,7
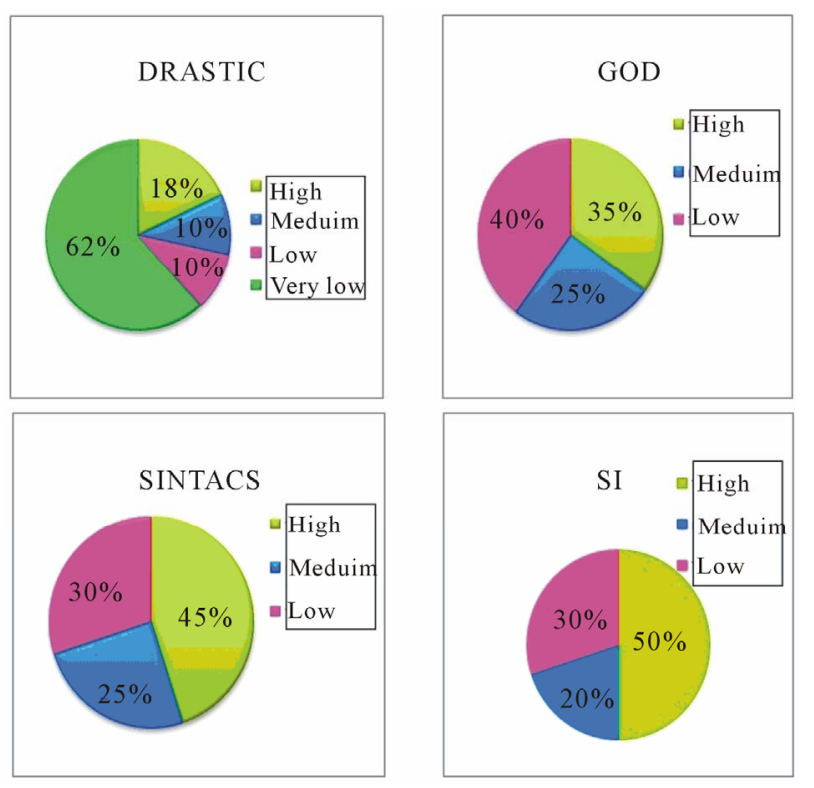

Figure 9. Statistical comparison between the four models.

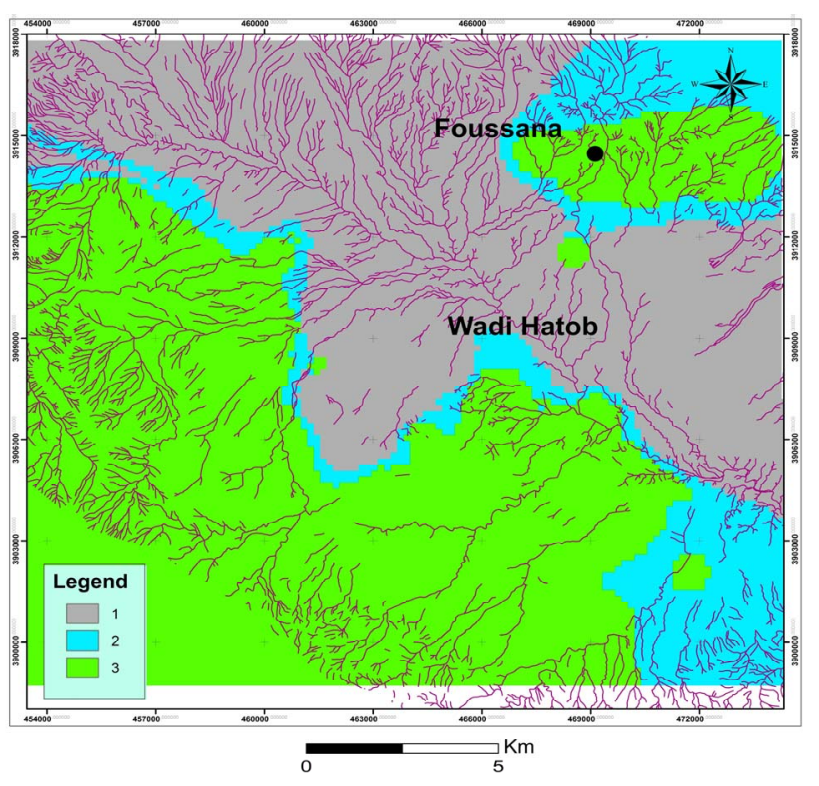

Figure 10. SI vulnerability map.

Table 6. Evaluation criteria of degree of vulnerability: SI. Model.

\begin{tabular}{cc}
\hline SI Vulnerability & Vulnerability index \\
\hline Low & $<45$ \\
Medium & $45-64$ \\
High & $65-84$ \\
Very high & $85-100$ \\
\hline
\end{tabular}

and 1 (Table 8). Zones which have index value between $0,0-1$, and 3 are the less vulnerable.

A statistical comparison among the vulnerability maps generated by each method has been carried out. The Fig- 


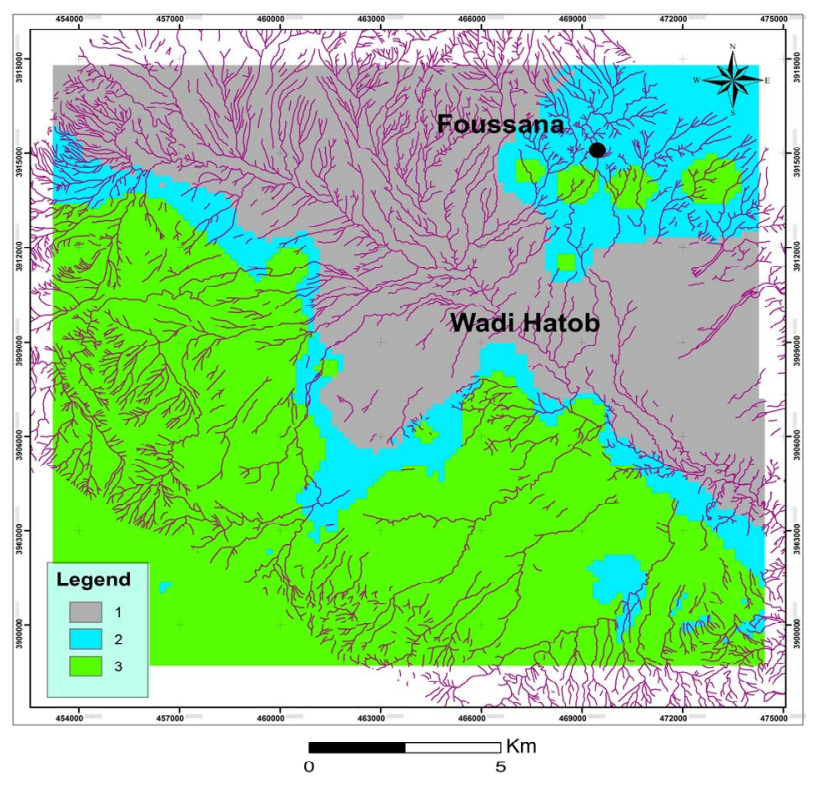

Figure 11. SINTACS vulnerability map.

Table 7. Evaluation criteria of degree of vulnerability: GOD model.

\begin{tabular}{cc}
\hline SINTACS Vulnerability & Vulnerability index \\
\hline Low & $<106$ \\
Medium & $106-186$ \\
High & $187-210$ \\
Very high & $>210$ \\
\hline
\end{tabular}

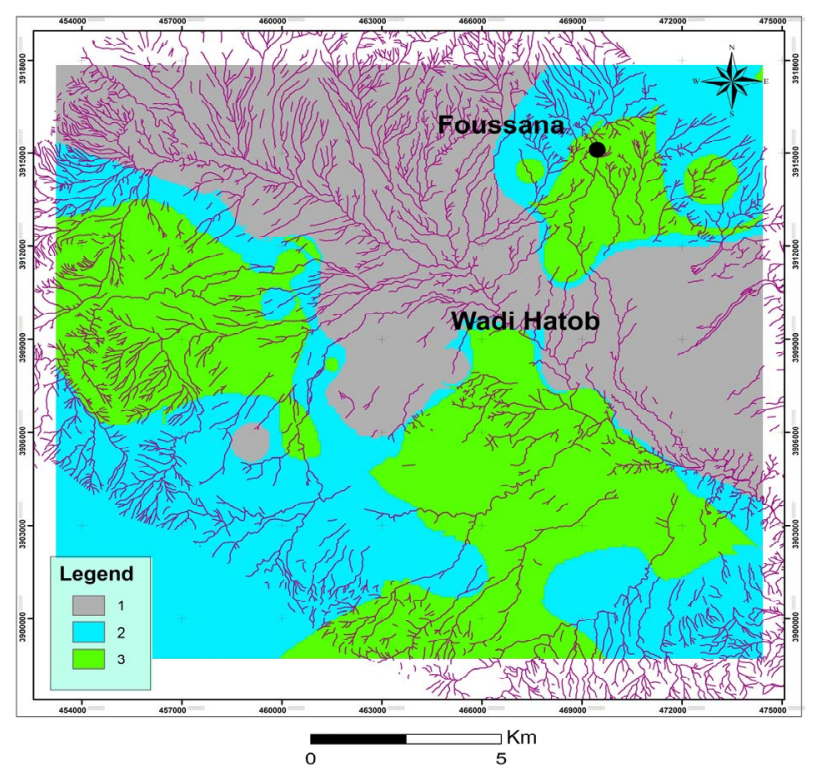

Figure 12. GOD vulnerability map.

ure 12 shows the difference of classification between the used methods of vulnerabilities. On the one hand, this comparison shows a certain similarity between the results obtained using the SI and SINTACS methods [24,25].
Table 8. Evaluation criteria of degree of vulnerability: SINTACS model.

\begin{tabular}{cc}
\hline GOD Vulnerability & Vulnerability index \\
\hline Low & $0.1-0.3$ \\
Medium & $0.3-0.5$ \\
High & $0.5-0.7$ \\
Very high & $0.7-1$ \\
\hline
\end{tabular}

On the other hand, the DRASTIC map classification shows different results. We see much more of a class at the DRASTIC method, this method is thus more suitable to use in our case.

Finally, we conclude that a specific vulnerability study using the "modified DRASTIC" method especially in Nitrate, is more recommended to this type of environment. It helps to protect the most vulnerable areas and to guide investors to have decision.

\section{Conclusions}

The GIS techniques use, to identify contamination risk by mapping, is primarily due to the automatization of certain operations. The database which is "behind" each layer can anytime be updated. In addition, the use of GIS facilitates the rapid visualization of some elements in the map by selecting them from the attribute table. Vulnerability and the land use maps, contamination data and groundwater quality can be used in view of a rapid and correct evaluation of pollution risk. By using this technology, we are assured that the information will be used in an efficient manner.

The models application showed that Foussana groundwater was characterized by moderate to high vulnerability degrees.

The most vulnerable areas to pollution is located in the southern part. It has been affected by a major fault: the "Fault Kasserine". Added to that, the groundwater overexploitation, the high permeability, the lithologic variability, that are marked mainly by quaternary alluvium and Miocene sandstones, and the relatively low topography, facilitates the rainwater infiltration and accumulation. Waters are easily accompanied by various geochemical elements coming from toxic pesticides and their extensive use in farmland, and wastewater. In high vulnerability areas, we shouldn't allow additional high risk activities in order to obtain economic advantage and to reduce environmental pollution hazard.

The GIS developed is a good decision tool. It is an efficient method for water resources management to evaluate vulnerability. The results are a way to avoid possible contamination water.

\section{Acknowledgements}

The authors thank the members of the Offices Regional of Agricultural Development of Tunis and Kasserine, Mr. 
Abdel kader Sliman and Mr. Ourtani , Mr Hamzoui for their collaboration and for documents that are available to us. The author would also like to express their appreciation to Mr. Mohamed Ajmi, Mohamed Hafedh hamza, and Mrs Fadhila darragi from Faculty of Science of Tunisia.

\section{REFERENCES}

[1] N. Edoulati, S. Boutaleb, I. Bettar and A. Ouchbani, "Contributions of Chemical and Isotopic Tools for Understanding the Groundwater Modes Recharge and Flow in the Lower Cretaceous Aquifer in the Moroccan Sahara," Journal of Water Resource and Protection, Vol. 5, No. 2, 2013, pp. 183-199. doi:10.4236/jwarp.2013.52020

[2] L. Pervinquere, "Geological Study of Central Tunisia," Ph.D. Thesis, Es-Sci. University, Paris, 1903, 360 pages.

[3] S. Witczak, R. Duda and A. Zurek, "The Polish Concept of Groundwater Vulnerability Mapping," In: A. J. Witkowski, A. Kowalczyk and J. Vrba, Eds., Groundwater Vulnerability Assessment and Mapping, International Conference of Groundwater Vulnerability Assessment and Mapping, Ustron, 2004, pp. 62-76.

[4] A. Rahmn, "A GIS Based DRASTIC Model for Assessing Groundwater Vulnerability in Shallow Aquifer in Aligarh, India," Applied Geography, Vol. 28, No. 1, 2008, pp. 32-53. doi:10.1016/j.apgeog.2007.07.008

[5] A. Tadesse, T. Bosona and G. Gebresenbet, "Rural Water Supply Management and Sustainability: The Case of Adama Area, Ethiopia," Journal of Water Resource and Protection, Vol. 5, No. 2, 2013, pp. 208-221. doi:10.4236/jwarp.2013.52022

[6] P. Pathak, A. K. Chourasia, S. P. Wani and R. Sudi, "Multiple Impact of Integrated Watershed Management in Low Rainfall Semi-Arid Region: A Case Study from Eastern Rajasthan, India," Journal of Water Resource and Protection, Vol. 5, No. 1, 2013, pp. 27-36. doi:10.4236/jwarp.2013.51004

[7] M. A. Sophocleous, "Combining the Soil Water Balance and 475 Water Level fluctuation Methods to Estimate Natural Groundwater Recharge: Practical Aspects," Journal of Hydrology, Vol. 124, No. 3-4, 1991, pp. 229-241 doi:10.1016/0022-1694(91)90016-B

[8] S.Saidi , S Bouri . H.Ben Dhia (2010) Sensitivity analysis in groundwater vulnerability assessment based on GIS in the Mahdia-Ksour Essaf aquifer, Tunisia: a validation study. Hydrol. Sci. J. 56(2):pp1-17.

[9] S. Saidi , S Bouri, H. Ben Dhia and B. Banselme, "A GIS-Based Susceptibility İndexing Method for Irrigation and Drinking Water Management Planning: Application to Chebba-Mellouleche Aquifer, Tunisia," Agricultural Water Management, Vol. 96, No. 12, 2009, pp. 16831690. doi:10.1016/j.agwat.2009.07.005

[10] L. Pervinquere, "Geological Study of Central Tunisia," Ph.D. Thesis, Es-Sci. University, Paris, 1903, 360 pages.

[11] H. Philip, H. Andrıeux, J. Dlala, M. Chich and L. Ben Ayed, "Tectonic Evolution Mio-Plio-Quaternary Kasserine Gap (Central Tunisia) Involvement in the Recent Geo- dynamic Evolution of Tunisia," Bulletin de la Societé Geologique de France, Vol. 8, 1986, pp. 559.

[12] A. Kadri, "Evolution Tectono-Sedimentary (Aptian-Quaternary) Dj. Koumine, Hamra Lessouda (Central Tunisia)," 3rd Cycle Thesis, University Paris-11, Orsay, 1988, 221 pages.

[13] H. Zouari, "Structural Studies of Jebel Chaambi (Central Tunisia) Relationship between the Mineralization and Structure," 3rd Cycle Thesis, University of Franche-Comté, Besançon, 1984, p. 335.

[14] P. F. Burollet, "Contribution to the Study of Stratigraphic Central Tunisia," Ann. Mines and Geol. Tunis, Vol. 18, 1956, pp. 1-350.

[15] M. H. Hanmza, A. Added, A. Ben Mammou, S. Abdeljaoued and R. Rodriguez, "Assessment of Vulnerability to Pollution Potential by Pesticides, Groundwater Inshore Alluvial Plain of Metline-Ras Jebel-Raf Raf, North-East of Tunisia, According to DRASTIC Me'thode Applique'e by the Systems of Geographic Information," International Journal of Coal White Water, Vol. 2004-2005, 2004, pp. 86-94.

[16] C. J. Philes, "The Geostatistical Modeling of Spatial Variability and Its Applications," Thesis, University Pierre et Marie Curie, Paris, 2004, 71 pages.

[17] B. Evans, B. M. and W. L. Myers, "A GIS-Based Approach to Evaluating Regional Groundwater Pollution Potential with DRASTIC," Journal of Soil and Water Conservation, Vol. 45, 1990, pp. 242-245.

[18] P. Sunil, et al., "GIS Techniques for Groundwater Contamination Risk Mapping," Natural Resource Management, 2011.

[19] B. Engel, B. A., Navulur, K. C. S., B Cooper. S. and L. Hahn, "Estimating Groundwater Vulnerability to NonPoint Source Pollution from Nitrates and Pesticides on a Regional Scale,” In: K. Kovar and H. P. Nachtnebel, Eds., Application of Geographic Information Systems in $\mathrm{Hy}$ drology and Water Resources Management, IAHS Press, Wallingford, 1996, pp. 521-526. http://www.iahs.info / redbooks/235.htm

[20] S. Saidi, S. Bouri and H. Ben Dhia, "Sensitivity Analysis in Groundwater Vulnerability Assessment Based on GIS in the Mahdia-Ksour Essaf Aquifer, Tunisia: A Validation Study," Hydrological Sciences Journal, Vol. 56, No. 2, 2011, pp. 288-304. doi:10.1080/02626667.2011.552886

[21] B. Shiferaw, C. Bantilan and S. P. Wani, "Policy and InStitutional Issues and Impacts of Integrated Watershed Management: Experiences and Lessons from Asia," In: B. Shiferaw and K. P. C. Rao, Eds., Integrated Management of Watersheds for Agricultural Diversification and Sustainable Livelihoods in Eastern and Central Africa: Lessons and Experiences from Semi-Arid South Asia, Proceedings of the International Workshop, Nairobi, 6-7 December 2004, pp. 37-52.

[22] R. S. Deshpande and M. N. Murthy, "Watershed Development Approach and Experience of National Watershed Development Program in the Country," Journal of Rural Development, Vol. 18, No. 3, 1999, pp. 453-469.

[23] J. F. Aranyossy, "The Contribution of Isotope Techniques 
to Study the Recharge under Constraints Techniques and Climate Extremes," Diploma for Accreditation to Supervise Research in Sciences, University of Paris-Sud, Orsay, 1991, p. 576.

[24] A. T. Bennet, J. H. Lehr and R. J. Petty, "DRASTIC: A Standardized System for Evaluating Groundwater Pollu- tion Potential Using Hydrogeologic Settings," US Environment Protection Agency, EPA/600, 1987.

[25] J. Sara and T. Katz, "Making Rural Water Supply Sustainable: Report on the Impact of Project Rules," UNDP, World Bank Water and Sanitation Program, 1997. 